\title{
SURVEI MOTIVASI OLAHRAGA BERSEPEDA PADA MASSA PANDEMI COVID-19 DI MASYARAKAT KABUPATEN KOTAWARINGIN BARAT
}

\author{
Muhammad Rizal 1), Bertika Kusuma Prastiwi ${ }^{2)}$, Pandu Kresnapati ${ }^{3)}$ \\ ${ }^{1}$ Fakultas Pendidikan Ilmu Pengetahuan Sosial Dan Olahraga, Universitas PGRI Semarang \\ Email: Rizalbagong8@gmail.com \\ ${ }^{2}$ Fakultas Pendidikan Ilmu Pengetahuan Sosial Dan Olahraga, Universitas PGRI Semarang \\ Email: Bertikakusumaprastiwi@upgris.ac.id \\ ${ }^{3}$ Fakultas Pendidikan Ilmu Pengetahuan Sosial Dan Olahraga, Universitas PGRI Semarang \\ Email: pandukresnapati@upgris.ac.id
}

\begin{tabular}{l}
\hline Artikel Info \\
\hline Koresponden penulis : \\
Muhammad Rizal \\
Email Rizalbagong8@gmail.com \\
$\square$ Diterima 28 Juni 2021 \\
$\square$ Direview 18 Januari 2022 \\
$\square$ Disetujui 29 Januari 2022 \\
$\square$ Dipublikasi 31 Januari 2022
\end{tabular}

Kata Kunci: Survei, motivasi, bersepeda.

\begin{abstract}
Abstrak
Tujuan untuk mengetahui bagaimana motivasi masyarakat berolahraga sepeda pada massa pandemi covid-19 di Kabupaten Kotawaringin Barat. Tujuan dalam penelitian ini adalah untuk mengetahui motivasi masyarakat berolahraga sepeda pada massa covid-19 di Kabupaten Kotawaringin Barat. Metode yang digunakan dalam penelitian ini adalah deskriptif kualitatif. Sumber data penelitian ini bersumber pada masyarakat yang melakukan aktivitas olahraga bersepeda pada massa pandemi covid-19. Data yang digunakan dalam penelitian ini adalah observasi, wawancara dan dokumentasi yang dilakukan di lapangan. Hasil penelitian adalah faktor instrinsik yang sangat mempengaruhi motivasi bersepeda pada massa pandemi covid-19 ada empat kriteria dan kriteria yang paling besar adalah covid-19 dan faktor estrinsik yang sangat mempengaruhi motivasi bersepeda pada massa pandemi covid-19 ada empat kriteria dan kriteria yang paling besar adalah teman/komunitas. Berdasarkan hasil penelitian yang terurai maka dapat disimpulkan bahwa faktor yang paling banyak mempengaruhi adanya trend olahraga bersepeda di wilayah kotawaringin barat adalah faktor instrinsik, maka terbentuklah olahraga yang menjadi trend bersepeda di Kabupaten Kotawaringin Barat yaitu olahraga sepeda.
\end{abstract}

\begin{abstract}
Aim in this study is to find out how the motivation of the community to exercise bicycles during the COVID-19 pandemic in West Kotawaringin Regency. The purpose of this study was to determine the motivation of the community to exercise bicycles during the Covid-19 mass in West Kotawaringin Regency. The method used in this research is descriptive qualitative. The source of this research data comes from people who carry out cycling sports activities during the COVID-19 pandemic. The data used in this study were observations, interviews and documentation conducted in the field. The results of the study are the intrinsic factors that greatly affect the motivation to cycle during the COVID-19 pandemic, there are four criteria and the biggest criteria are covid-19 and the intrinsic factors that greatly affect the motivation for cycling in the masses of the covid-19 pandemic are four criteria and the biggest criteria. are friends/community. Based on the results of the unraveled research, it can be concluded that the factor that most influences the trend of cycling in the West Kotawaringin area is the intrinsic factor, so that a sport that becomes the cycling trend in West Kotawaringin Regency is formed, namely cycling.
\end{abstract}




\begin{tabular}{|c|c|}
\hline Unipa Sumabaya & $\begin{array}{c}\text { Journal STAND: Sports and Development } \\
\text { http://jurnal.unipasby.ac.id/index.php/stand/about/submissions } \\
\text { jurnal.stand@unipasby.ac.id }\end{array}$ \\
\hline
\end{tabular}

\section{PENDAhUluan}

Sering dijumpai di tengah-tengah masyarakat setiap akhir pekan berbagai macam aktivitas olahraga dilakukan, mulai dari anak-anak, remaja, sampai dewasa dan orang usia lanjut. Semua gemar berolahraga, pagi hari beraktivitas di lapangan, di pinggir jalan, atau di halaman parkir yang luas dijadikan tempat untuk melakukan aktivitas jasmani atau berolahraga

Secara umum orang memahami olahraga merupakan salah satu aktivitas jasmani yang dilakukan oleh orang, sekelompok orang dengan tujuan untuk mencapai kebugaran jasmani ( Mutohir,T. C, 2011: 1)

Dalam Undang-Undang Nomor 3 Tahun 2005 disebutkan bahwa olahraga adalah segala kegiatan sistematis untuk mendorong, membina, dan mengembangkan potensi jasmani, rohani dan sosial.

Aktivitas olahraga dilakukan oleh semua orang tanpa melihat perbedaan usia. Kegiatan olahraga sangat jauh dari nuansa diskriminatif, perbedaan budaya, agama, dan derajat seseorang. Semua bisa berdiri tegak bersamasama, bergerak bersama, lari bersama-sama dengan riang gembira.

Selama ini perkembangan olahraga semakin pesat bahkan sudah memasyarakat, sehingga sebagian masyarakat telah memandang olahraga sudah menjadi bagian dalam hidupnya, bahwa melakukan olahraga merupakan sesuatu yang sama pentingnya dengan kebutuhan yang lainnya (Abror Hisyam, 1991: 1).

Olahraga pada dasarnya merupakan kebutuhan setiap manusia di dalam kehidupan, agar kondisi fisik dan kesehatannya tetap terjaga dengan baik. Oleh karena itu, manusia ingin berusaha menjaga kesehatannya dan salah satu cara agar kesehatan tetap terjaga dengan baik adalah melalui olahraga.

Dalam kehidupan sehari-hari agar dapat menunjang kesehatan, perlu adanya tindakan atau upaya yang dilakukan. Upaya kesehatan adalah setiap kegiatan untuk memelihara dan meningkatkan kesehatan yang bertujuan untuk mewujudkan derajat kesehatan yang optimal bagi masyarakat.

Dalam Undang-Undang kesehatan nomor 36 tahun 2009 upaya kesehatan adalah setiap kegiatan dan/atau serangkaian kegiatan yang dilakukan secara terpadu, terintregasi dan berkesinambungan untuk memelihara dan meningkatkan derajat kesehatan masyarakat dalam bentuk pencegahan penyakit, peningkatan kesehatan, pengobatan penyakit, dan pemulihan kesehatan oleh pemerintah dan/atau masyarakat. Kesehatan adalah keadaan sehat, baik secara fisik, mental, spritual maupun sosial yang memungkinkan setiap orang untuk hidup produktif secara sosial dan ekonomis.

Kesehatan sangat penting bagi manusia, karena tanpa kesehatan yang baik, setiap manusia akan sulit dalam melaksanakan aktivitasnya sehari-hari. Semakin padatnya 
http://jurnal.unipasby.ac.id/index.php/stand/about/submissions jurnal.stand@unipasby.ac.id

aktivitas yang dilakukan seseorang menjadikan mengabaikan masalah berolahraga. Dalam upaya menjaga kesehatan dan kebugaran, masyarakat tidak bisa terlepas dari kegiatan olahraga. Banyak sekali jenisjenis olahraga yang dapat dilakukan, salah satunya adalah bersepeda.

Bersepeda adalah olahraga yang mudah di lakukan karena simpel dan juga bisa di lakukan oleh siapa saja, tak kenal usia, muda, tua, atau anak-anak sekalipun. Di Denmark telah di lakukan penelitian manfaat bersepeda, dan hasilnya bersepeda mampu mengurangi 40 $\%$ resiko kematian, Baik wanita maupun laki laki. Dari laporan yang terdapat di American Journal of Public Health tahun 1986 dengan bersepeda kita bisa memiliki umur yang lebih panjang ketimbang orang-orang yang tidak berolahraga bersepeda. Selain itu juga bersepeda dapat menambah relasi kekerabatan dengan orang lain. Dengan bersepeda kita akan banyak membakar lemak di dalam tubuh, hal ini bisa meningkatkan metabolisme tubuh dan membantu kita dalam menurunkan berat badan.

Sepeda merupakan alat untuk bersenangsenang, melakukan petualangan, dan menjaga kesehatan. Di samping merupakan sarana transportasi yang hemat. Kendaraan beroda dua ini meluncur di jalan raya dengan dikayuh dua kaki ( RM. Ismunandar, 1996: 1)

Motif seringkali diistilahkan sebagai dorongan atau kekuatan yang ada di dalam dirinya sendiri . Dorongan atau tenaga tersebut merupakan gerak jiwa dan jasmani untuk berbuat. Motivasi merupakan salah satu hal yang sangat penting diperhatikan dalam berolahraga, karena hal ini sangat mempengaruhi kinerja seseorang yang melakukan olahraga tersebut. Motivasi penting karena dengan motivasi ini diharapkan setiap seseorang yang berolahraga mau bekerja keras dan antusias untuk mencapai kebugaran jasmani yang memadai. Menurut George yang dikutip oleh Ibrahim (2008:164) bahwa "Motivation is the desire within an individual that stimulate him or her to action". Motivasi adalah "hasrat di dalam diri seseorang yang mendorong untuk bertindak". Pendapat lain diungkapkan oleh para ahli motivasi, yang dikutip oleh Komarudin (2013:24) bahwa motivasi adalah "dorongan yang berasal dari dalam atau dari luar diri individu untuk melakukan suatu aktivitas yang bisa menjamin kelangsungan aktivitas tersebut, serta dapat menentukan arah, haluan dan besaran upaya yang dikerahkan untuk melakukan aktivitas sehingga dapat mencapai tujuan yang telah ditetapkan".

Dalam olahraga sepeda bisa menjadi cara lain menikmati hari untuk mengusir kebosanan di tengah pandemi virus Covid-19, yang mengharuskan banyak orang lebih sering berada di rumah saat ini. Tak hanya itu, bersepeda juga merupakan salah satu kegiatan meningkatakan imun tubuh, yang menyenangkan, sehingga bisa menjadi 
pengganti olahraga buat kamu yang masih malas berolahraga.

Akan tetapi tidak untuk pecinta olahraga bersepeda mereka tetap melakukan aktifitas bersepeda ditengah pandemi Covid-19. Di kabupaten Kotawaringin Barat khususnya beberapa pekan terakhir makin tingginya masyarakat yang memenuhi jalanan dengan bersepeda, mereka memenuhi jalan dipinggiran kota. Pada masa pandemi covid-19 ini, bupati kabupaten Kotawaringin Barat ibu Hj. Nurhidayah menghimbau "agar masyarakat bisa tetap sehat dengan berolahraga akan menambah daya tahan tubuh kita, salah satunya dengan bersepeda,"

Karena peneliti ingin mengetahui tentang tingkat motivasi olahraga bersepeda pada massa pandemi Covid-19 di masyarakat Kabupaten Kotawaringin Barat, Dalam langkah awal tentunya penulis telah melakukan observasi yang di lakukan dengan mengambil data di lapangan sebanyak 15 responden untuk data yang di hasilkan nantinya. Survei ini dilakukan pada tanggal 20 Desember 2020 - 28 Desember 2020 yang berlokasi di jalan Panglima Utar sampai jalan Bahari di Kecamatan Kumai Kabupaten Kotawaringin Barat. Data hasil di lapangan menunjukkan bahwasannya masyarakat mengetahui apa itu virus Covid-19 dan apa saja gejalanya, pada massa pandemi Covid-19 ini masyarakat mulai menyadari bahwa pentingnya berolahraga menurut mereka salah satu olahraga yang sangat cocok dilakukan yaitu bersepeda. Menurut responden dilapangan mengatakan bahwasannya olahraga bersepeda menjaga dan meningkatkan daya tahan tubuh, sehingga olahraga bersepeda lebih banyak di lakukan atau di gemari dari pada olahraga lainnya dimassa pandemi Covid-19 saat ini, olahraga bersepeda menjadi trend yang dimana dapat dilihat dari hasil survei bahwa penjualan sepeda lebih meningkat dan pengguna sepeda meningkat drastis di kabupaten Kotawaringin Barat, ratarata pesepeda sudah banyak yang mengikuti protokol kesehatan pada saat bersepeda.

Berdasarkan beberapa alasan tersebut maka peneliti akan mengadakan penelitian tentang "Survei Motivasi Olahraga Bersepeda Pada Massa Pandemi Covid-19 Di Masyarakat Kabupaten Kotawaringin Barat".

\section{METODE PENELITIAN}

Penelitian ini adalah penelitian dengan metode kualitatif. Menurut Moleong dalam (Mujib \& Suparingga, 2013) menyatakan penelitian kualitatif adalah penelitian untuk memahami fenomena tentang apa yang di alami oleh subjek penelitian misalnya perilaku, persepsi, motivasi, tindakan, dan lain-lain secara holistik dan dengan cara deskripsi dalam bentuk kata-kata dan bahasa, pada suatu konteks khusus yang alamiah dan dengan memanfaatkan berbagai metode ilmiah.

Penelitian ini untuk mendeskrifsikan datadata mengenai motivasi masyarakat berolahraga sepeda pada massa pandemi 
http://jurnal.unipasby.ac.id/index.php/stand/about/submissions jurnal.stand@unipasby.ac.id

covid-19. Setting penelitian ini berada di wilayah Kabupaten Kotawaringin Barat meliputi jalan Bendahara sampai Bundaran Monyet kecamatan diantaranya Kecamatan Kumai dan Jogging Trek Lanud Iskandar Kecamatan Arut Selatan.

Sumber data pada penelitian ini dilakukan dengan observasi, wawancara, dan dokumentasi yang di dapatkan dilapangan. Sumber data penelitian ini adalah masyarakat. Sedangkan data pada penelitian ini berupa kata-kata dan tindakan, subjek penelitian, dan dokumentasi.

Teknik pengumpulan data pada penelitian ini dilakukan dengan caraaobservasi, wawancara, dan dokumentasi. Menurut Sugiyono ( dalam Ma'sumah, 2015:49 ), "Observasi merupakan cara yang penting untuk mendapatkan informasi yang pasti tentang orang, karena apa yang dikatakan orang belum tentu sama dengan apa yang dikerjakan". Observasi dilakukan di lokasi dimana banyak masyarakat Kabupaten Kotawaringin Barat melakukan kegiatan olahraga Bersepeda seperti Jogging Trek Lanud Iskandar dan jalan menuju Bundaran Monyet Kecamatan Kumai. Menurut Moleong (2012:16) wawancara merupakan "Percakapan yang dilaksanakan dua pihak, terdapat pewawancara yang mengajukan pertanyaan dan terwawancara yang memberikan jawaban atas pertanyaan yang diajukan". Wawancara dilakukan dengan mewawancarai 20 resondent yang di temukan di lapangan serta lengkap dengan dokumentasinya. Dokumentasi adalah dokumen yang artinya barang-barang tertulis. Didalam melakukan metode dokumentasi, peneliti menyelidiki benda- benda tertulis seperti buku-buku, majalah, dokumen, peraturan-peraturan, notulen rapat, catatan harian dan lain sebagainya (Arikunto 2010:201).

Analisis data adalah proses mencari dan menyusun data secara sistematis yang diperoleh dari hasil observasi, wawancara, dan dokumentasi dengan mengorganisasikan data ke dalam kategori, menjabarkan ke dalam unitunit, melakukan sintesa, menyusun ke dalam pola, memilih mana yang penting dan yang akan dipelajari, dan membuat kesimpulan, sehingga mudah dipahami dan temuannya dapat di informasikan kepada orang lain (Sugiyono, 2014:334). Langkah-langkah analisis selama di lapangan dengan model Miles dan Huberman terdiri dari:

1. Reduksi Data (Data reduction)

Reduksi data merupakan proses berfikir sensitif yang memerlukan kecerdasan dan keluasan, serta kedalaman wawasan yang tinggi. Mereduksi data berarti merangkum, memilih hal-hal yang pokok, memfokuskan pada hal-hal yang penting, dicari tema dan dan polanya dan membuang yang tidak penting (Sugiyono, 2014:338). Pada tahap ini peneliti mereduksi data-data yang diperoleh dari hasil observasi, wawancara dan dokumentasi.

2. Penyajian Data (Data display) 


\begin{tabular}{|c|c|}
\hline Unipa Sumabaya & $\begin{array}{c}\text { Journal STAND: Sports and Development } \\
\text { http://jurnal.unipasby.ac.id/index.php/stand/about/submissions } \\
\text { jurnal.stand@unipasby.ac.id }\end{array}$ \\
\hline
\end{tabular}

Menurut (Sugiyono, 2014:341) menyajikan data dalam bentuk uraian singkat, bagan, hubungan antara kategori flowchart dan sejenisnya. Dengan penyajian data akan memudahkan untuk memahami apa yang terjadi, merencanakan kerja, selanjutnya berdasarkan apa yang telah dipahami. Penyajian data dalam penelitian tentang survei motivasi olahraga bersepeda pada massa pandemi Covid-19 di masyarakat Kabupaten Kotawaringin Barat berupa uraian naratif yang mudah dipahami.

\section{Penarikan Kesimpulan}

Setelah dilakukan penyajian data, maka langkah selanjutnya adalah penarikan kesimpulan. Ini didasarkan pada reduksi data yang merupakan jawaban atas masalah yang diangkat dalam penelitian. Apabila kesimpulan yang dikemukakan pada tahap awal didukung oleh bukti-bukti yang valid dan konsisten saat peneliti kembali ke lapangan mengumpulkan data, maka kesimpulan yang dikemukakan merupakan kesimpulan yang kredibel (Sugiyono, 2014:345).

\section{HASIL DAN PEMBAHASAN}

Penelitian ini dilakukan utuk mengetahui motivasi masyarakat berolahraga sepeda pada massa pandemi covid-19. Penelitian ini di laksanaka pada tanggal 1 Maret 2021 sampai dengan 30 Maret 2021. Dalam temuan hasil penelitian, peneliti melakukan wawancara kepada 20 respondent. Berikut merupakan hasil peneliti setelah melakukan penelitian melalui hasil observasi, wawancara dan dokumentasi.

Analisis data yang dilakukan pada penelitian ini menggunakan aturan triangulasi yang mana data yang akan dilihat adalah hasil dari wawancara, observasi dan dokumentasi. Berdasarkan penelitian yang dilakukan melalui wawanacara masayarakat yang melakukan olahraga bersepeda dikarenakan ingin menjaga kesehatan dikala pendemi dan juga sebgai ajang rekreasi hal ini senada dengan obeservasi yang dilakukan bahwa mereka yang bersepeda memiliki usia 15-50 tahun karena pada usia yang demikian mereka masih mampu bersepeda sehingga bisa menjaga kebugaran badan dan yang lebih mendukung lagi mereka bersepeda dengan menerapkan protokol kesehatan kemudian berdasarkan dokumentasi terlihat wilayah yang digunakan untuk bersepeda adalah wilayah yang nyaman sehingga selain berolahraga mereka juga bisa sambil berekreasi untuk menghilangkan kejenuhan. Berdasarkan triangulasi antara wawancara, obsevasi dan dokumentasi terdapat kekonsistenan hasil penelitian sehingga data yang diperoleh adalah data yang kredibel. Sehingga bisa disimpulkan faktor yang paling mempengaruhi trend olah raga bersepeda dimasa pendemi adalah faktor instrinsik.

\section{KESIMPULAN}

Berdasarkan hasil penelitian dan pembahasan dapat disimpulkan bahwa: 


\begin{tabular}{|c|c|}
\hline Unipa Sumabaya & $\begin{array}{c}\text { Journal STAND: Sports and Development } \\
\text { http://jurnal.unipasby.ac.id/index.php/stand/about/submissions } \\
\text { jurnal.stand@unipasby.ac.id }\end{array}$ \\
\hline
\end{tabular}

1. Faktor instrinsik yang sangat mempengaruhi motivasi bersepeda dikala pandemi covid-19 ada empat kriteria dan kriteria yang paling besar adalah covid19.

2. Faktor ekstrinsik yang sangat mempengaruhi motivasi bersepeda dikala pandemi covid-19 ada empat kriteria dan kriteria yang paling besar adalah teman/komunitas.

Berdasarkan hasil penelitian yang terurai maka dapat disimpulkan bahwa faktor yang paling banyak mempengaruhi adanya trend olah raga bersepeda di wilayah kotawaringin barat adalah faktor instrinsik, maka terbentuklah olahraga yang menjadi trend bersepeda di Kabupaten Kotawaringin Barat yaitu olahraga sepeda.

Berdasarkan hasil penelitian maka penulis perlu menyampaikan saran sebagai berikut:

1. Bersepeda dikala pandemi covid-19 bukan hanya sekedar trend yang tentunya bisa hilang sewaktu-waktu, tetapi menjadi kebiasaan yang baik di kalangan masyarakat kotawaringin barat.

2. Selama berolahraga sepeda diharapkan tetap memenuhi protokol kesehatan yang dinajurkan pemerintah, sehingga wabah ini segera hilang dan kita bisa berolahraga dengan tenang.

\section{REFERENSI}

Arikunto. (2010). Prosedur Penelitian Suatu Pendekatan Praktik. Jakarta: Bumi Aksara. Hal. 201.
Hisyam, Abror. 1991. Sarana dan Prasana Olahraga. Semarang: IKIP

Ibrahim, Rusli. (2008). Modul Psikologi Olahraga. Bandung: FPOK

Ismunandar, RM. 1996. Olahraga Balap Sepeda. Semarang: Dahara Prize.

Komarudin. (2013). Psikologi Olahraga. Bandung. PT. Remaja RosdaKarya

Ma'sumah. Siti.i2015. "Pengaruh Disiplin

Belajar Kelas IV Sekolah Dasar Negeri Se-

Daerah Binaan II Kecamatan Petahana

Kabupaten Kebumen'”. Skripsi. Universitas

Negeri Semarang: Semarang. Hal.49

Mujib, A., \& Suparingga, E. (2013). Upaya

Mengatasi Kesulitan Siswa Dalam OperasiPerkalian Dengan Metode Latis. Prosiding Seminar Nasional Matematika dan Pendidikan Matematika FMIPA UNY, (hal. 1-6). Yogyakarta.

Mutohir T. C. 2011. Berkarakter dengan Berolahraga. Surabaya: Java Pustaka Group.

Sugiyono. (2014). Metode Penelitian Pendidikan. Bandunga: Alfabeta

Undang-undang RI No 3 Tahun 2005 Tentang Sistem Keolahragaan Nasional.

Kementrian. Negara Pemuda dan Olahraga Republik Indonesia.

Undang-undang RI No 36 Tahun 2009

Tentang Kesehatan. 